\title{
ATELIÊ DE PINTURA 1336: AULAS E EXPERIÊNCIAS
}

Entrevista com o professor e pintor Alphonsus Benetti Entrevistadores: Antonio José dos Santos Junior (UFSM)

Stéfani Trindade Agostini (UFSM)

Milena Regina Duarte Corrêa (UFSM)

\section{Como o professor descreve este espaço do ateliê? Não uma descrição formal apenas dos objetos ou física, mas de tudo $\circ$ que aconteceu naquele ambiente?}

Alphonsus Benetti [A. B.] O ateliê 1336, a criação do ateliê 1336 é parte do projeto do currículo, deste currículo que vocês cursaram, e que foi implantado em 1990. Ele tem a estrutura que vocês conhecem, com os Fundamentos I e II, que duram dois semestres, depois os ateliês de quatro semestres no mínimo ou seis. Então a estrutura central dele, do currículo, eram os ateliês. As pessoas escolhiam os ateliês a partir dos orientadores, nas áreas que tinham interesse, ele previa isso. A norma sempre foi essa: quem escolhia eram os alunos, depois do Fundamentos como vocês já conhecem. É a partir daí que se cria o Ateliê 1336, que vocês conhecem de pintura, e que eu vou falar mais um pouco. Era um ateliê que eu considero diferenciado em relação aos outros porque ele se origina, vamos dizer assim, da antiga sala de pintura que existia com o Carriconde, que faleceu em 1981. Na época, antes do curso novo, com jeito de ateliê, com alguma situação que lembrava mais os ateliês, nós tínhamos a escultura, a pintura e a tapeçaria. Eles tinham um pouco isso, e era só, mas as pessoas não escolhiam. Seguiam um currículo parecido com este que vão fazer hoje, que são disciplinas para você ir cursando até se formar. Quem tinha uma militância, uma atividade um pouco mais como vocês faziam em ateliê, eram as pessoas que estavam 


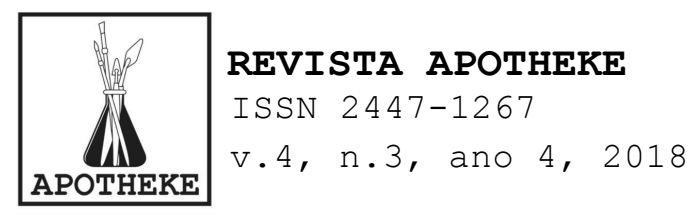

nesses ateliês. Os outros faziam só aulas, em outras salas, o tempo todo, teóricas e práticas. As aulas, por exemplo, de desenho, eram dadas em vários lugares. Se era para fazer desenho, faziam desenho, se era para fazer história da arte, faziam história da arte. Não tinha um ateliê de desenho, com espaço mais fixo; tinha a pintura, que era uma sala determinada, a escultura e um pouco a sala de tapeçaria.

\section{E quem cuidava destes ateliês, por exemplo de escultura e tapeçaria?}

[A. B.] Eram pessoas mais ligadas à área, eram pessoas que trabalhavam também em outras disciplinas. Mas, por exemplo, o Carriconde era o professor de pintura, ele tinha a sala lá em cima, que é a sala da Suzana hoje, naquele lugar era a sala de pintura do Carriconde. Era uma sala na qual não se tinham outras aulas lá a não ser a pintura. Lá estavam os cavaletes, algumas mesas, modelo, tinta, essas coisas. A escultura era lá embaixo. Na época a sala de escultura estava onde é hoje a Percussão, naquele canto do prédio, no térreo. Pra se fazer escultura precisavam de materiais como pedra, argila, madeira, serra, solda. Não dava para mexer muito na sala, colocar ai outras coisas. E numa outra sala no segundo piso, a tapeçaria que, na época que cheguei era uma área muito forte na universidade, com várias pessoas fazendo e expondo mesmo fora do Brasil. Depois foi perdendo força. Na tapeçaria havia pelo menos vinte alunos, na escultura uns dois ou três, e na pintura uns dois ou três também. Os outros levavam o "currículo" para fazer em casa e iam embora. Então a pintura, no caso do 1336, ele surge disso. Quando começamos a trabalhar na pintura, fizemos uma caracterização toda diferente do espaço, seu aprofundamento na questão de ateliê, de ficar produzindo ali, de ser um QG de produção de pintura, de sair dali só pra fazer os apoios e voltar para trabalhar, pintar, 


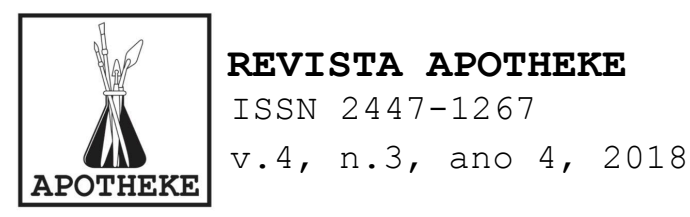

fazer seminários, coisas que o Carriconde não fazia, como eu já falei para vocês.

\section{Isto se deu com a entrada do senhor no ateliê?}

[A. B.] Sim. Isso o Carriconde não fazia, até porque ele, como eu falei tinha problemas de saúde, alcoolismo, aparecia pouquíssimo, uma hora ou duas a cada quinze dias. Ele vinha ao ateliê dar uma olhada. Com ele nunca se fez seminário, nunca se desenhou com modelo. A gente desenhava com modelo, por nossa conta, mas ele nunca estava ali.

\section{Em que ano o senhor assumiu o ateliê?}

[A. B.] Bom, eu começo a trabalhar, como professor em 1980. Por volta de 82, 83, passo a trabalhar também na pintura, mas na sala do Carriconde, atendendo pessoas que queriam fazer pintura. Ele tinha falecido em 81. Eu comecei na pintura para atender essa gente. O 1336 começa a ser formatado com o "currículo novo", a partir de 1990. O currículo começa a ser discutido em 86. Toda a fundamentação filosófica dele, o embasamento é de 86. Foram quatro anos discutindo para montar o curso novo. Então tem isso, né, o ateliê. Você me perguntou mais alguma coisa sobre o ateliê que eu de repente esqueci.

\section{Uma descrição deste espaço, do espaço do ateliê.}

[A. B.] Esse espaço na verdade retoma coisas que são peculiares aos ateliês de pintura ao longo da história, que são espaços de convivência, de convívio, de grupos de pessoas que trabalham naquele lugar com um objetivo comum. E nesse sentido, ele é um espaço que também abarca mais elementos, abarca outros conhecimentos, outras facetas. Ele abarca, muitas vezes, questões da vida das pessoas, questões de aprender não só a pintura, mas de conhecer outros contextos. 


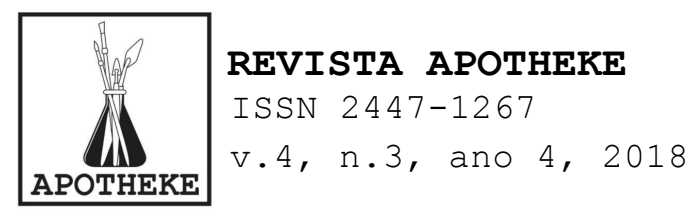

Então no ateliê de pintura, eu sempre procurei um pouco esta característica que ultimamente esta se perdendo. Aquele era um espaço de convívio, de produção, de criação, uma espécie de quartel general, como eu digo, de quem estava no ateliê. Implica as pessoas acreditarem, são vocês que escolhiam (não era eu quem escolhia as pessoas), por acreditarem na pintura. Resgata elementos antigos, quer dizer, do surgimento dos ateliês lá na Renascença, quando as pessoas iam para os ateliês espontaneamente porque acreditavam naquilo que iam fazer ali. E muitas vezes, ficavam anos trabalhando num ateliê antes de sair por conta própria. Não é o caso que hoje temos na universidade, de um tempo limitado e sair. Era um espaço que abarcava muitas coisas; não era o ensino técnico da pintura. Eu nunca me detive muito neste lado técnico da pintura. Até por que eu acho que não se pode ensinar técnica e nem composição; ensinar técnica e composição implica entrar na expressão da pessoa, então isso eu não ensino. O Carriconde pegava o pincel e pintava para as alunas. "Como é que se pinta isso? Me dá aqui que eu pinto para ti." Eu nunca fiz isso com vocês, porque dizer como você compõe ou dizer como você pinta, significa estar passando a minha expressão pessoal. Então a técnica, para mim, não tem muita importância, tem importância a criação, tem importância como é que vocês e o pessoal do ateliê descobriam coisas, como é que se pinta, como é que se cria. Como é que vocês surpreendiam a gente com coisas, coisas boas e, às vezes, coisas não muito boas também surpreendiam a gente. Faz parte, é isso. A gente discutia, em ateliê, muito a questão de como está a arte, qual é o espaço da pintura no mundo de hoje, quais são as questões filosóficas, as questões da sociedade, quais são as questões sociológicas. E com essas coisas vinha o cinema, os filmes, e outras questões de vida. Os hábitos, a educação, quais são os princípios, quais são os valores que as pessoas têm, que os jovens têm. Sobre isso, 


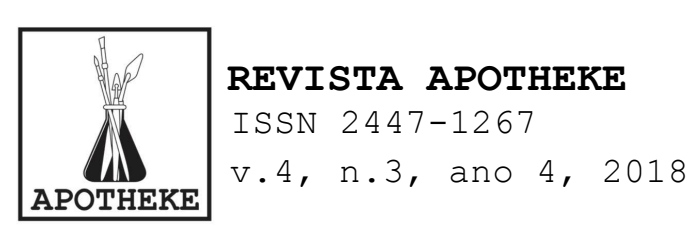

desde o início a gente conversou muito. Abarcava assim, mais um conjunto de conteúdos. E uma coisa que eu sempre privilegiei, que eu procurei estruturar, era tentar privilegiar o caminhar com os dois pés, com a teoria e com a prática, mas favorecendo um pouco mais a prática em ateliê, a criação. Se vocês lembrarem eu sempre falava: "tem que pintar, vamos pintar, vamos fazer um balanço, vamos ver como é que está a pintura". Não que eu não goste de teoria e dos livros; gosto muito, tenho sempre coisas para ler, para ver; mas acontece que eu considerava no curso, a passagem de vocês por outras áreas. Alguns passaram por História, por Filosofia, por Estética, Arte no Rio Grande do Sul; vocês tinham outras áreas que faziam um aporte. Se você centrar mais na parte teórica, o pessoal não produz, não pinta. Basta ver os ateliês de universidades da França de hoje, em que ninguém pinta, só ficam discutindo pintura. Para mim sempre foi fundamental isso; o ateliê é um lugar de produção, tem que pintar, tem que produzir. Pode não acontecer algo bom, mas pode vir alguma surpresa na produção, é a produção que sustenta a arte, a pintura. No ateliê eu sempre gostei deste aspecto: é a partir da produção que, por exemplo, vocês podem escrever, discutir, analisar, referenciar, fazer comparações. É a partir disso, que se tem moeda para negociar. Se você só têm teoria, você pode até não concordar, mas vai acabar citando citações, citações, citações de outra gente. Até vocês chegarem a serem autores de respeito, para serem citados, vai dar trabalho, e não vão aceitar muito fácil isso. Agora se vocês criarem um trabalho sensacional, ele pode gerar estudos, mobilizar pessoas que escrevem. Eu conheço, por exemplo, um livro de um filósofo alemão, o livro inteiro a partir de um artista brasileiro, uma pintora. O filósofo alemão fez uma obra inteira a partir da obra dela. E a obra o que era? Era uma exposição. Então os ateliês tinham esse perfil, e esse perfil 


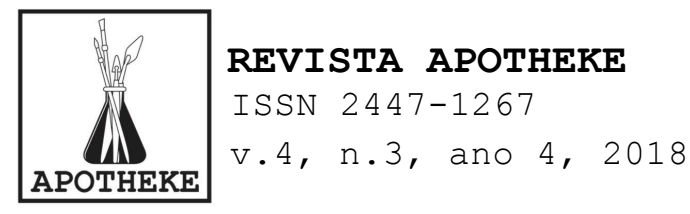

fazia parte da filosofia do curso naquela época. Peciar foi o coordenador este trabalho todo; foi sempre um grande defensor disso. O ateliê dele, enquanto trabalhou na escultura, era assim também. E outros ateliês que se "puxaram" eram assim, tinham esse perfil.

\section{A proposta daquele novo currículo surgiu de uma necessidade específica? O que existia antes dele?}

[A. B.] Sim. O currículo anterior, implantado durante o regime militar, mostrava-se desestruturado e exaurido. Lembra muito o currículo que estão fazendo agora, que é por disciplinas. A mudança foi pelos alunos. O Peciar não era nada burocrata, nunca quis ser coordenador, não trabalhava com isso, detestava burocracia. Ele falou: "nós vamos fazer este trabalho porque os alunos pediram". E teve o apoio de todo o pessoal do curso.

\section{Eles conheciam o currículo da Escola de Montevidéu?}

[A. B.] Não, eles pediram que se fizesse um currículo diferente, melhor. Conheciam algumas ideias que ele comentava, de como era lá. Como era o currículo no Uruguai, na Europa, mais o pensamento dele e dos autores que ele usou. Ele também conhecia muito as propostas de autores. O que havia anteriormente era o seguinte: o currículo era por disciplina, disciplinas com cargas horárias em torno de sessenta horas. Fazia vestibular, passava, chegava lá e eles te davam na coordenação, quando você começava o curso, uma folha impressa com o currículo que se podia cursar. Começava por semestre, primeiro semestre, segundo, terceiro, quarto, divididos por uma linha separando os blocos de semestrais. Eles te entregavam isso quando você começava o curso. Se você entrou no bacharelado em Artes Plásticas, (na época Desenho e Plástica), vai fazer isso aqui. No primeiro semestre te 


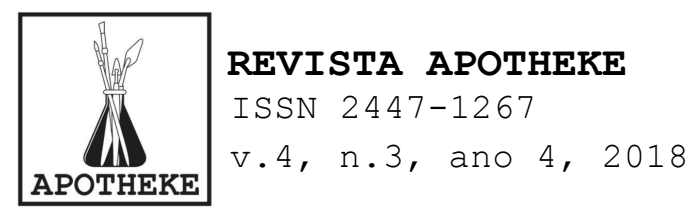

matricula aqui, depois vai seguindo. Quando você chegava no fim da sequência estava formado. Havia o Desenho Geométrico, dois Desenhos Geométricos, duas Geometrias Descritivas. Isso não era oferecido nas Artes, você tinha que se matricular para os dois desenhos e para as duas geometrias na Engenharia, com professores da Engenharia, juntos com alunos daquele curso. Não se relacionavam conosco, dava-se aula para engenheiro. E o que acontecia? Você podia se matricular num lugar, em outro, buscar geometria aqui ou lá, o aluno ficava, vamos dizer assim, bastante autônomo para se mexer, não tinha a questão da turma ou do grupo. Ficava com a turma que conseguisse. E outra coisa: a sequência dos Desenhos, da História da Arte, do que ofereciam, não significava que o mesmo professor da área ia te dar aula. Começava com um, depois continuava com outro, podia improvisar alguém, chamar alguém para "quebrar o galho", caso - professor estivesse afastado. Quem dava Desenho não era sempre um professor de Desenho. Histórias da Arte, eram oito. Então, chamavam mais docentes, às vezes, o pessoal que não era da teoria dava História da Arte, tinha que lecionar por que a pessoa precisava se formar. Aquele currículo era assim. Por isso vejo que hoje, quando estão voltando àquela situação, de operar por disciplinas avulsas, estão voltando aquilo que eu fazia. Uma das fundamentações do "currículo novo", aquele que chamávamos de novo, que discutimos a partir de 86 e que ele defendeu muito, é o seguinte: as pessoas são diferentes, têm interesses diferentes, têm capacidades diferentes, têm expressões diferentes. Uns gostam mais de pintura, outros mais de desenho. Você tem que trabalhar, em artes, a diferença das pessoas. O anterior era para pessoas todas iguais. Todos nós fazíamos a mesma coisa, de ponta a ponta. A mesma quantidade de tarefas. Então o pensamento do "novo currículo" era o seguinte: não se faz a mesma quantidade e nem se faz a mesma coisa. Se faz muito mais do que se tem interesse. Alguma coisa 


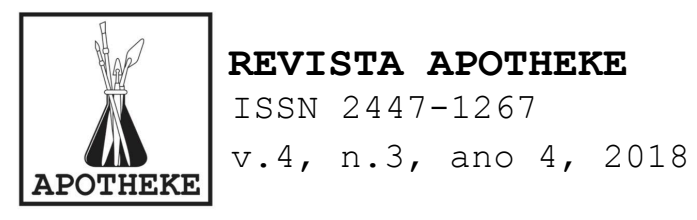

não se faz, se não cabe para você ou para ele. Em arte é assim, as pessoas são diferentes, cada artista é diferente, trabalha com desejos diferentes. Com um tempo diferente, tem interesses diferentes do colega. Essa uniformização não funcionava e não funciona. Esse foi um dos pontos centrais que a gente mudou quando fez o novo currículo. Por exemplo, os alunos tinham escolha. Você escolhe onde quer ir, o teu colega de Fundamentos vai para outras áreas, porque tem interesses diferentes. Quanto você faz de cada coisa? Ah, você faz as quatro pinturas, você faz seis pinturas, cinco, ou faz menos. No apoio, faz duas, faz três, uma, quatro. Depende do interesse, da necessidade e da motivação de cada pessoa. Vai se desenvolvendo o estudante, enriquecendo ele com essas situações diferentes. Cada um tinha um currículo diferente, pessoal, que atendia as diferenças, aspirações, anseios que os alunos têm.

\section{Na contemporaneidade se fala muito em diferença, em valorizar as diferenças, e este currículo que está sendo implementado agora vai para o lado oposto. Não é contraditório?}

[A. B.] É muito contraditório. Tem-se um discurso que consegue vender isso, como os políticos. Quando eu fiz, naquela época, aquele curso, todo pessoal que se formou comigo fez a mesma grade que eu fiz. A diferença que eu tive com os outros é a questão de ateliê porque, na época, eu fui para a pintura. Éramos somente três fazendo pintura. Eu fazia aquela base igual aos outros, mas ia todos os dias pintar. Em horário extra, lá na sala que hoje é o ateliê da Susana. Ia lá sozinho ou com alguém pintar, por que eu morava na Casa do Estudante. Levantava de manhã e ia para a aula. Aí às vezes não tinha aula no outro turno, então ia pintar. Ia até a noite, às vezes, pintar lá com algum colega junto. Na manhã seguinte 


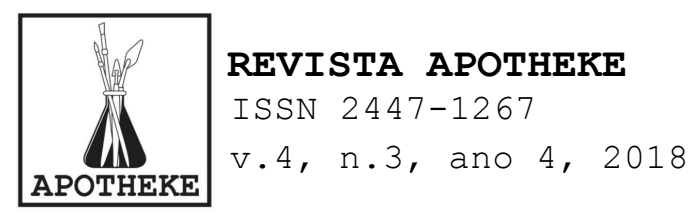

tinha disciplina, de tarde ia para aula, fazia os desenhos que - professor pedia e continuava a pintar. Era algo que os colegas não faziam, faziam só as disciplinas. A minha formação tem alguma coisa diferente por poder ficar no ateliê e ser um espaço que não tinha outras aulas, como eu disse antes. O orientador não estava, o orientador não dizia nada, não aparecia. E eram seis semestres de pintura naquele tempo. Antes eram oito, no Regime Militar encurtaram para seis. Eu esperei, inclusive, porque não ofereceram pintura em um semestre. Na verdade, eu tive uma orientação legal, com um professor que orientou o trabalho, com o Yeddo Tietze. Ele faleceu agora há pouco, lá em Porto Alegre, com oitenta anos. O Yeddo assumiu no final do último semestre porque o Carriconde estava muito doente, estava afastado, internado. Aí chamaram o Yeddo que era formado em pintura, trabalhava com tapeçaria e tinha feito toda uma estadia na França. Era bom pintor sempre pintou, até o fim da carreira seguiu pintando. E - Yeddo tinha outro comportamento, ele vinha para a aula conosco. No sexto semestre quando a gente estava terminando ele vinha para o ateliê, olhava o trabalho, conversava com a gente. Então foi uma parte boa, essa parte final. Não sei se estou respondendo o que vocês querem.

\section{Era mais essa parte a respeito do ateliê.}

[A. B.] Um modelo de ateliê vem da Europa a partir das antigas guildas dos profissionais, que reuniam os artesãos e os artistas. São grupos que trabalham em um espaço o tempo todo. Os grandes pintores, por exemplo Leonardo, foi ao ateliê do Verrocchio, trabalhou há um tempo. Outros trabalharam em outros ateliês durante dez, doze, quinze anos juntos com o mestre no ateliê. O próprio Giotto tinha muita gente no ateliê. Então, às vezes, o mestre e eles trabalhavam todos juntos em alguma encomenda, tarefas em igrejas, nas paredes 


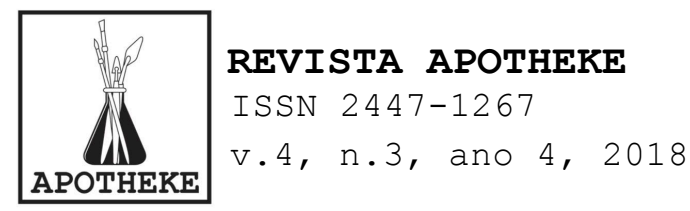

dos palácios, o que dava muito trabalho. No começo os auxiliares faziam certas partes da figura, e o mestre fazia outras. Geralmente rostos e mãos era o mestre que fazia. E certas partes de fundo, roupagem, algumas peças de roupa, eram os auxiliares que estavam aprendendo a pintar. Estavam sempre juntos. E não devia ser ruim, porque na Itália sempre há um bom vinho para se compartilhar.

\section{E o ateliê não só como espaço físico, mas quase como uma filosofia de trabalho, o que o senhor tem a dizer?}

[A. B.] Eu tenho anotações de um intercambista da Escola de Montevidéu e ele fala disso, ele escreveu sobre isso. Ele fala que para ele era uma forma de vida, uma maneira de viver, não só de pintar. Encontrei lá no armário do ateliê essas anotações e inclusive a proposta para ele pintar naquele semestre. Tem muito disso, e a melhor coisa é essa, é uma coisa que eu pouco tive, essa experiência mais rica que envolve a vida em ateliê. Mas tive depois, por exemplo, com o Peciar. O Peciar chegou em 75, eu estava no segundo ano do curso, como aluno. Então, foi o convívio com o Peciar que me enriqueceu muito quanto a essas questões de arte, de viver, de trabalhar. Ele era uma pessoa que, todos os dias, quando te encontrava, perguntava: "o que está pintando?" Em qualquer lugar. E ele era um cara que, além disso, escrevia, publicava; mas a pergunta dele era sempre essa. Ou se alguém fizesse escultura ou cerâmica perguntava: "O que está esculpindo?" "O que está modelando?" Então esse era o espírito de ateliê, tinha muito disso. Muita gente que esteve no ateliê e hoje está em outros lugares fala muito dessa coisa de "família", que tem saudade. Às vezes me escrevem, gente que há muitos anos passou pelo ateliê e dizem ter uma lembrança muito boa daquele grupo, que era uma família. No ateliê tu tens uma troca. Por exemplo, tu tens um orientador que troca 


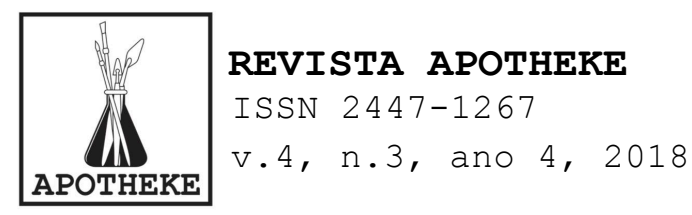

conhecimento contigo, que te orienta, mas o aprendizado paralelo que se tem em ateliê, que é o aprendizado que se tem com os colegas de diferentes tempos lá dentro, esse é muito enriquecedor. Desde que existe a forma de ateliê em arte é muito assim. Estava o Verrocchio de mestre, havia o Leonardo, outros recém-chegados, outros mais avançados, aí o Leonardo avançou muito e foi trabalhar, mas todo mundo ali aprendia junto. É assim. Essas trocas paralelas a gente conversava com - Peciar, era muito importante, ele achava isso fundamental. Por isso a idéia de estar juntos e fazer seminários com todos. No ateliê é sempre importante ter algum horário na semana em que todos estarão juntos. Porque, se não existe isso você começa a voltar para situação das disciplinas isoladas, por exemplo, você nunca se encontra com as pessoas no ateliê, ou só se encontra com certas pessoas em certos horários e não conhece os outros, já que não existe mais um ambiente de verdadeiro ateliê. Vai se desmanchando. Há que se ter momentos em que todo mundo deve estar aí, os que recém chegaram, os que não conhecem nada, os que estão preocupados, os caras que ainda estão sendo meio escanteados pelos outros. Tem que estar todos aí. os mais velhos e os que estão saindo, juntos, a coisa é muito mais rica assim.

\section{E a relação que há entre o Peciar e as literaturas, algumas referências de viés anarquista, também se reflete na concepção daquele currículo?}

[A. B.] Ele tem um pouco do viés anarquista, é bom esclarecer isso. Ele é uma pessoa que tem em sua formação, algumas correntes mais libertárias, vamos dizer assim, não tanto anarquista. Era uma pessoa com fortes traços dos libertários pacifistas. Uma pessoa que considera certas linhas do anarquismo como o russo Kropotkin, que é pacifista, dos Italianos pacifistas, como Luigi Fabbri, que foi um líder dos 


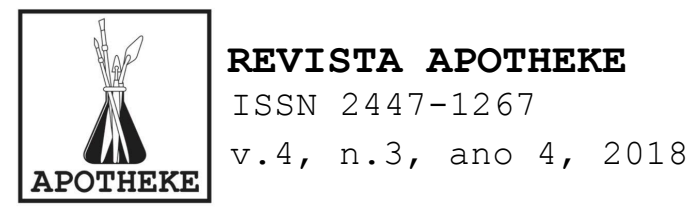

movimentos de trabalhadores lá no começo quando não se tinha nem jornada de trabalho ou horário definido. E tem a questão das pedagogias, que ele leva em conta. O Peciar tem, em sua formação a influência das chamadas pedagogias libertárias. A questão da pedagogia do Ivan Illich, dos Franceses, esses grupos todos que trabalham com as pedagogias novas, contra as tradicionais, como as pedagogias autogestionárias, as pedagogias de autogestão. Claro que com as suas diferenças, ajustando as coisas, porque foram experiências, na época, fascinantes para alguns, mas que, em outras situações, mostraram a necessidade de correções. Por exemplo, experiências com crianças e autogestão davam problema. Era difícil bancar experiências com crianças, o projeto muitas vezes desandava, ou acabavam não fazendo nada. Mas ele tem influência disso, das pedagogias autogestionárias e libertárias. Ele era um cara que conhecia muito isso, mas não era um anarquista militante; ele aproveitou o melhor dessas situações. No final do texto onde explica o currículo, ele cita uma bibliografia que só tem grandes obras, uma lista de grandes obras da época atual e anteriores também. Ali deve aparecer alguma coisa das pedagogias libertárias ou autogestionárias. A questão destas pedagogias é essencial para nossa área. Só para esclarecer melhor, se você não tem liberdade e autonomia você faz o quê em arte? Se não existe liberdade para criar, desenhar, pintar, e não há autonomia para fazer o que gostarias de fazer, a nossa área não funciona. Admito que até possa funcionar em outras áreas, não acredito muito, na engenharia, na matemática, te dizem, você tem que fazer isso aqui e tchau. Agora, na nossa área, para que alguém crie alguma coisa tu não podes tirar essas duas coisas; a pessoa tem que ter liberdade para criar e tem que ter autonomia para fazer. Não há liberdade sem autonomia da pessoa. O Peciar nunca perdeu isso de vista, por isso ele 


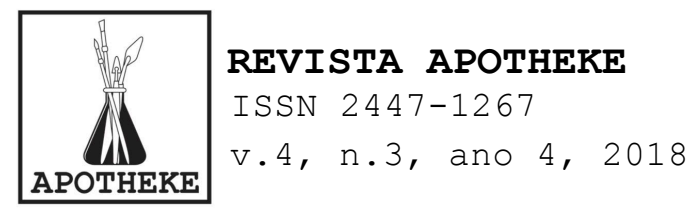

sempre trabalhava com este perfil. Essa era a questão, e entendo que nem todos têm que ter este perfil, não é todo mundo que entende isso de ateliês. O Peciar também colocava muito isso: primeiro, não dá para pedir para quem está chegando, para quem não conhece nada o que ele gostaria de fazer. Pedir isso para que a pessoa não conhece. O segundo ponto, não dá para exigir uma postura crítica dos que estão chegando, porque ainda não conhecem. Os que se formaram, os que saíram os que estão saindo são os que têm uma visão melhor para falar e comparar. Naquela ocasião, voltando um pouco (a proposta foi impressa em 86, e implementada em 90) então ele foi muito discutido. E desde aquele momento, por exemplo, na coordenação existia um grupo que trabalhava com o Peciar (não eram do diretório), eram alunos do curso. Ele foi muito debatido com os alunos e nós tínhamos, na época, quase 30 professores. Tudo foi discutido detalhadamente, passo a passo até o fim. Quando ele foi implantado não tinha nenhum professor contra, todos estavam de acordo. Ele foi aprovado com elogios no CEPE foi elogiado pelo conselho, porque era uma proposta única na universidade, não tinha outra igual na época. Houve trabalho de esclarecimento nos mínimos detalhes de como é que ficava isso na aula, no ateliê. As assembléias de alunos eram assembleias com muita gente, perguntando como seria aquilo, em sala de aula. O porquê dos Fundamentos, por que fazer a Graduação final daquele jeito. Então se pode ver que 4 anos para levar a proposta, para implantar ela e começar a funcionar, naquela ocasião foi um bom tempo. Só que tudo foi elaborado juntamente com os alunos, pois eles trabalhavam com - Peciar na coordenação. Ele não mexia com burocracia, com máquina de escrever, nada disso. A secretária e os alunos é que digitavam as coisas, os alunos faziam o trabalho burocrático; ele escrevia à mão, e passava as folhas escritas para digitarem. 


\section{E quando o Ateliê 1336 passou a existir naquele lugar que conhecemos?}

[A. B.] A partir da implementação do currículo, eu comecei a trabalhar lá, até pouquinho antes disso. Não sei precisar exatamente, mas próximo dos anos 90 nos instalamos naquela sala. Foi na redistribuição dos espaços, quando se implantou o currículo, que previa o seguinte: podem existir dois ateliês de pintura, ter dois ateliês de cerâmica (como tinha), podem ter dois ateliês de escultura, com o Peciar e o José. $\mathrm{Na}$ distribuição de espaços, aquela era uma sala de aula, só com a primeira parte onde a gente tomava café, não tinha o adendo (a "capela"), que a gente conseguiu mais tarde porque havia muita falta de espaço ali. Mais tarde transformamos uma sala de aula, que só tinha mesas. Trocamos por mesas menores. Fizemos cavaletes, porque não tinha o suficiente, fomos formatando ele com jeito de ateliê. E mais tarde aquela passagem lá dentro (a "capela"), que foi o departamento e o curso que propuseram. A partir dali o 1336 ficava naquele espaço. Foi uma situação que - curso em conjunto decidiu, porque antes eu estava trabalhando no ateliê da frente que viria a ser do Casanova. Foi assim.

\section{E o café, organizado de um jeito que era distinto de todos os outros ateliês, por que daquilo?}

[A. B.] Isso aí foi comigo, essa coisa meio casa, de família, de grupo que trabalha junto. A gente começou a fazer café para juntar o pessoal, em uma mesinha pequena no início, depois uma mesa maior, e depois emendamos ela. O café se revelou uma coisa muito interessante, principalmente nos primeiros tempos (e até recentemente). Era um local, um momento de muita conversa e discussão de assuntos importantes interessantes em 


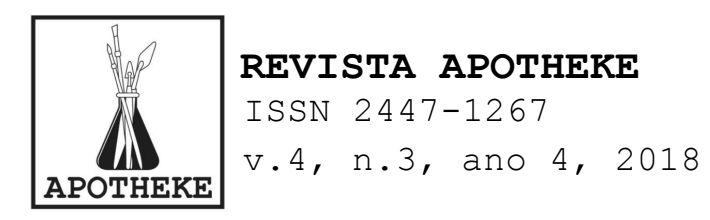

relação à arte. Hoje, recentemente, não é mais assim. o café continua melhor hoje em dia, tem mais coisas, mais comida, mais doces, mas o melhor papo sumiu. Era um espaço que a gente discutia muitas coisas. Lembro de conversas com a Jociele Lampert, com pessoal que era aluno ali, conversas muito boas durante o café. Discutia-se questões que alguns ainda discutem agora; o que está acontecendo, as exposições, as matérias, notícias da semana, aconteceu isso, aconteceu aquilo. Vamos para São Paulo, tem a Bienal, tem aquela exposição que Fulano viu... O café servia para isso, e para juntar as pessoas. Eu sou uma pessoa muito de casa, tenho um pouco esse perfil, casa no sentido de lar. Onde eu moro tem que ser um lar. No conceito dos antigos romanos, lar é onde tem fogo, onde se faz comida e tem fogo. Eu sou uma pessoa que faz questão disso. Depois foram nos podando, não podia mais, proibiram. Ficou o café e o aquecimento vem dos aquecedores elétricos. No tempo que a gente tinha um fogão com gás, estava melhor; não era como aqui em casa, com fogão a lenha, mas.... Eu sempre prezei muito essa questão. Por exemplo, na família com os familiares, quando alguém senta na mesa antes e começa a se servir, eu vou xingar, pode ser minha sobrinha, meu sobrinho, meu irmão. Se colocamos na mesa as coisas, vamos sentar todo mundo junto, vamos nos servir, e vamos conversar. Esse negócio de ficar comendo e bebendo em avulso, então vão no McDonald's ou em outro lugar. Até porque eu não sou uma pessoa que sinta muita fome, não me interessa tanto a comida, mas sim estar junto. E os ateliês antigos tinham um pouco esse aspecto, tinha isso, às vezes as pessoas até dormiam no ateliê, naqueles ateliês. Quem não tinha melhores condições ficava no ateliê. Passava a noite tinha algum lugar para dormir, tinha fogo, fogão nos antigos ateliês para se aquecer, por exemplo, na época do Renascimento. Fazia um frio danado, às vezes estava nevando lá fora, e os caras estavam no ateliê. Então tinha esse aspecto 


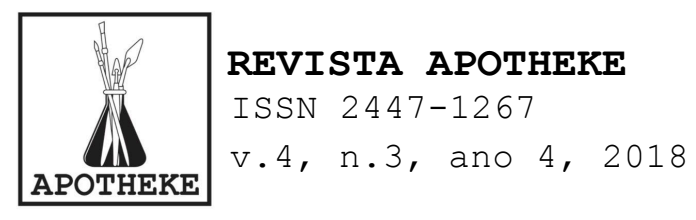

de ser um espaço... um lugar cálido, agradável. Hoje estão nos cortando quase tudo; o ateliê vai ficando frio, tem que ligar - "ar" para ficar um pouco quentinho. Temos até textos publicados sobre isso, que falam do nosso café, dizendo que faz muita diferença, o cheiro do café, o cheiro da terebintina, o cheiro das laranjas e bergamotas.

\section{No começo, as primeiras pinturas do ateliê se pareciam muito com as suas. Como o senhor entende isso? Por que acontecia?}

[A. B.] Isso acontece sempre, isso pode acontecer sempre, é normal. Eu encaro como normal, nunca tive "dedos" quanto a isso. Essa influência é uma coisa natural. Eu não pinto para ninguém, não busco influenciar alguém. A questão é que todos nós, seja Picasso ou quem for, no início da carreira constrói a partir de outros. A arte se cria a partir da arte. Sempre. E a influência que você busca nas pessoas, no Alphonsus, em quem quer que seja, é você que busca. Por outro lado, como a gente convive num grupo, tem princípios de arte e pintura que entendemos e defendemos, é normal que a gente se mobilize por um certo tipo de produção. Isso carrega influências, evidentemente. Pode servir como referência inicial, não quer dizer que o aluno vai seguir com aquela influência, mas é uma referência inicial para se começar a trabalhar. Outra coisa é - seguinte: as pessoas se influenciam reciprocamente, vocês, naquele lugar, se influenciam entre vocês e o professor influencia também. Não tem como fugir. Ninguém é neutro que não influencia em nada, nem ninguém. Se fosse assim os ateliês não funcionariam. E a arte também não funcionaria. Se você orientar um ateliê e os alunos fizerem um trabalho ao contrário, você tem um problema. Ou você não tem uma postura, não tem um projeto, não tem uma filosofia de arte; ou você não aparece no ateliê nunca para que aconteça qualquer coisa. Às 


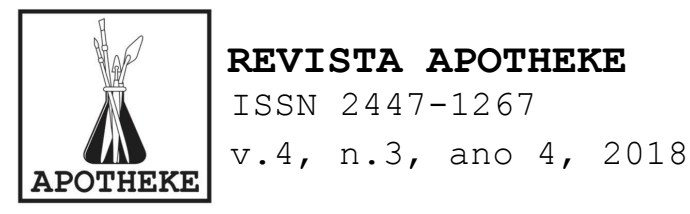

vezes, o cara não tem nenhuma influência e o orientador fica feliz, mas deveria dizer alguma coisa para esse aluno, porque pode estar fazendo uma bobagem. Eu sempre disse, até certo ponto não me preocupo com isso porque você busca influência para pintar para você trabalhar e construir um trabalho. Você acaba também, por exemplo, ao longo da vida tendo uma vasta gama de influências. Muitas vezes é um acervo de cores. Como você vê, alguns pintores trabalham com a cor mais saturada, outros com uma paleta mais baixa. Outros têm uma carreira longa, com uma pintura quase toda escura. São questões pessoais, partiram de algum ponto, tem que partir de algum ponto. E não é só na nossa área, mas também em outras áreas. Eu estava lendo um livro do Pamuk, Orhan Pamuk, um turco que é Nobel de Literatura. Falando de literatura, escreve sobre a vida dele como escritor e fala das influências que ele tem. Que a construção de um romancista se faz a partir dos outros romancistas, aqueles que ele admira. E ele conhece todos, leu tudo, ou seja, não se esconde as influências. Antes de ganhar - Nobel de Literatura ele já tinha em sua casa em Istambul, a biblioteca pessoal que continha $12 \mathrm{mil}$ livros. Todos os grandes autores, de qualquer parte do mundo, japoneses, chineses, russos, americanos, latino-americanos, ele conhece todos. E comenta qualquer um com grande qualidade. Nos diz que para ser um romancista tem que partir dos romancistas. Ele escreve de uma maneira que é dele, é um cara com uma literatura bem peculiar. Em uma parte, por exemplo, ele fala da literatura latino-americana, porque ele também se sente de terceiro mundo por ser da Turquia fora da Europa, na Ásia. E fala do escritor peruano Vargas Llosa, que trabalha nos Estados Unidos. Começa falando de um livro do autor peruano e, então, ele fala de todos os livros do Vargas Llosa; livros, artigos e mais artigos que se escreveram sobre o Vargas Llosa. Então é isso: você vê claramente o interesse, a vinculação, a 


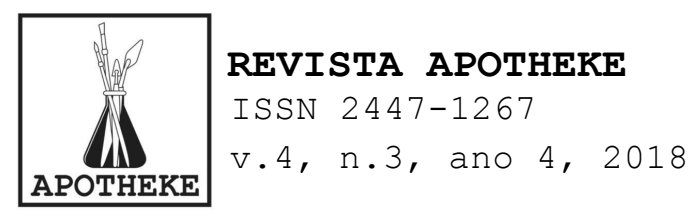

paixão de Picasso pelo Toulouse Lautrec, no início da carreira. Quando ele chega em Paris, Toulouse para ele... Tem coisas que são evidentes; ele usa o traço, o papel, o cartão, e as cores do Toulouse. O Toulouse estava vivo? Não, não era vivo. Você sente que Picasso está interessado, gostou muito da obra do pintor frânces. Vamos dizer que Toulouse influenciou o espanhol? Não, ele procurou a sua influência. Portanto, eu não posso me eximir disso. Porque eu, por exemplo, não gostaria de ser um orientador neutro, que não pudesse oferecer nada. No meu trabalho, sempre digo.... Nosso orientador era o Carriconde, a minha pintura tem a ver com o do Carriconde? Não, não tem nada a ver. Por que não tem a ver com a do Carriconde? Porque o Carriconde não dizia nada, nem aparecia no ateliê. Hoje eu vejo os trabalhos dele, na época também os desenhos as coisas que ele fazia, os princípios, as cores que ele usava, a maneira que ele usa o desenho. Não tem a ver comigo. Mas na época não tinha escolha, como só ele era professor de pintura e eu queria fazer pintura... Eu tenho influência de outras pessoas, por exemplo, do Peciar, que nunca foi meu professor. Tenho alguma coisa do Yeddo Tietze e, em termos próximos, de outros daqui do continente. Tanto de uruguaios, do Iberê Camargo e de outras figuras aqui do sul do Brasil que eu gosto muito. O Picasso dizia para as pessoas que mostravam seus trabalhos para ele, por exemplo o Brassaï: "Se for bom eu copio!" Não dá para ser neutro, e também não dá para evitar porque as pessoas procuram isso. Só que tem que ser uma coisa séria, depois você vai evoluindo, você vai amadurecendo. Tem que ir superando isso para buscar o teu trabalho; no início serve como um impulso para entrar em campo, conhecer as coisas, ver o que tem qualidade para depois tu teres, a partir desses elementos, onde mexer.

\section{Mas em algum momento parece que parou?}






[A. B.] Eu acho que tem isso. Mas eu também não estou preocupado com isso. Uma coisa que mudou também, é porque o pessoal do Ateliê pinta coisas mais diversificadas. Então às vezes fica difícil de perceber. Tem gente que trabalha muito com paisagem, eu já não trabalho muito com paisagem, então aparece menos quando as pessoas pintam paisagens, naturezasmortas, porque eu não pinto. Eu trabalho com figura humana. Então quando entra na figura humana as pessoas enxergam maior proximidade, às vezes. Por exemplo, quando analiso o trabalho do Pedro, lá no começo, a paisagem dele, tem muita coisa que eu gosto, provavelmente ele carrega alguma coisa que eu gostaria, que o Pedro usa, e o Rômulo usava. Só que aparece menos por que eu não trabalho com os mesmos temas. Mas todos procuram a boa pintura, seja na paisagem ou em qualquer tema. Quando a influência é sutil, é mais fácil, quando é escancarada é mais "brabo". Mas são coisas que eu não tenho como proibir ou evitar.

\section{Então o senhor acredita que as imagens que você produz reverberam nas imagens que os outros produzem?}

[A. B.] Sim, até porque se eu fizer uma exposição individual na Carriconde, por exemplo, eu não tenho como ter controle do que vai acontecer. Pode ter gente que goste, pode ter gente lá no início do Fundamentos que goste e comece a mexer com coisa parecida. Acontece com as pessoas isso, muito, sabe? Eu não sei quem é, por que não me dizem, muitas vezes se gostaram ou não gostaram do trabalho em exposição. Agora uma coisa é certa, você constrói arte a partir da arte.

\section{E nesse contexto, qual é a tua percepção sobre nosso trabalho? Sobre a investigação de cada um.}




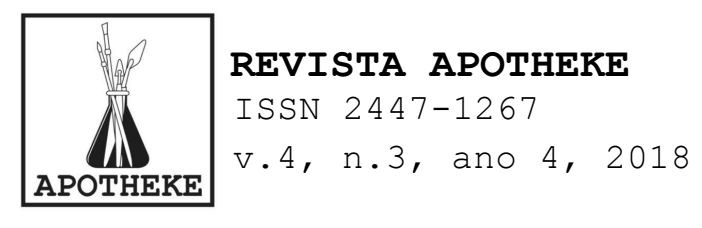

[A. B.] Eu vejo que vocês têm pontos em comum, na questão da pintura, do ateliê, mas tem faces diferentes no trabalho de cada um. A primeira coisa, as pinturas de vocês, do pessoal do ateliê, elas têm em comum o fato de que são pinturas, têm que ser pinturas; a linguagem é a primeira coisa que unifica o trabalho de vocês. A maneira que vocês lidam com as cores, com as massas, com a pincelada, também cria pontos em comum. Somase a isso, também, a compreensão do que é bom, do que tem qualidade em pintura, usando esses materiais, essas tintas. Às vezes, a compreensão é próxima entre vocês quanto ao que é bom em pintura. Isso cria pontos em comum na linguagem de vocês. Por exemplo, a pincelada, a textura, a espontaneidade no tratamento das coisas. Depois têm as diferenças. As diferenças entram por conta, vamos dizer, dos temas que vocês abordam, isso já é um ponto bem diferente no trabalho de cada um. Outra coisa é como vocês compõem o trabalho no suporte. Isso é bem peculiar, marca a diferença do trabalho de cada um, porque a composição de um trabalho no suporte é algo da expressão da pessoa. Tem a ver, muitas vezes, também o tamanho do suporte. Grande, pequeno. Por exemplo, os trabalhos da Milena geralmente são mais pequenininhos, já os trabalhos da stéfani são maiores, e o Júnior atua numa faixa de tamanhos mais intermediários. Isso faz diferença. Outra coisa são as cores, como vocês usam as cores, que também é diferente entre vocês três. E na pintura isso é importante, porque ela precisa da cor, precisa da tinta, das cores, e isso é diferente no trabalho cada um de vocês. Às vezes, a questão de usar um "filtro de cor" para o fundo, de não usar, atuar sobre questões estruturais já inicialmente, ou não. Às vezes os trabalhos de vocês, de uma série para outra, mudam acentuadamente, e tem gente que não muda muito. O trabalho da Milena é um trabalho que muda gradativamente, de maneira sutil. Mas nós temos gente que muda mais, o próprio Júnior, 


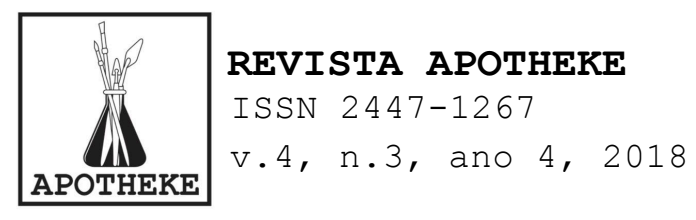

tem um trabalho que varia muito dependendo do tema que ele está trabalhando, do que ele tem em mente, com o que ele está vinculado, família, foto, rua, natureza. O trabalho muda rapidamente, muda a cor e outros elementos. São questões pessoais. O trabalho mais recente da stéfani, mudou muito nas dimensões e no tema; no entanto restringiu a cor, a cor ficou próxima em muitos deles, pois estava trabalhando uma paleta mais restrita, com uma pincelada mais solta, mais espontânea ocupando suportes maiores. São as diferenças que eu vejo no trabalho de vocês. O que eles têm em comum? Às vezes tem uma textura muito forte, uma pincelada, ou uma massa mais forte como tem na stéfani. Mas tem também no Júnior, uma massa mais cuidada, colocada de uma maneira mais ponderada, vamos dizer. E aí tem as naturezas-mortas da Milena, um pouco mais pictóricas, pequenas; paisagens, uma coisa com uma pincelada menor, curtinha. Existem pontos em comum entre vocês, e existem as diferenças. O que há em comum na pintura de vocês três, é que não tem coisas "alisadas", como se diz por aí no vulgar. Acho que os problemas que tem por aí na pintura, no trabalho de vocês não têm. E isso é uma coisa boa.

\section{Como o senhor acha que estas imagens do ateliê, o café, as pinturas que estão lá, os objetos, como isso se mostra em nosso trabalho, direta e indiretamente?}

[A. B.] No trabalho da Milena aparece mais, por pintar objetos como tema. Eu acho que isso repercute sim, tem repercussão. Em alguns de maneira mais explícita, em outros mais sutil. Faz parte desse ambiente, e os objetos que se fazem presentes, ele nos significam, eles não são neutros. Eles quase que dialogam com a gente. Por isso é que, muitas vezes, os objetos são tão importantes na casa de algumas pessoas; se tu retirares certos objetos da casa a pessoa pode até entrar em depressão. Porque, com os objetos pode haver essa relação. Se você observar a 


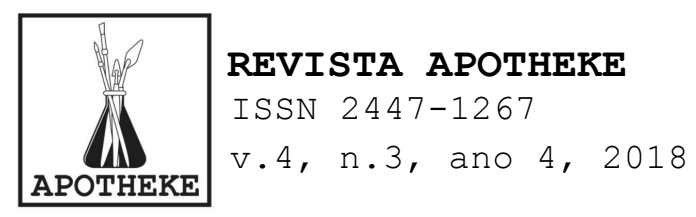

produção que está lá no ateliê disposta, tem trabalho aí de uns e de outros que você pode gostar, achar interessante, usar algumas referencias. Tudo isso pode influenciar o trabalho de vocês. É aquilo que eu disse, muitas vezes trata-se de um aprendizado paralelo entre o pessoal que frequenta o ateliê, não é falado, não é discutido, mas visto. Parte do que é produzido ali dentro, está exposto, fica nos cavaletes. Você passa, vê, e pensa: interessante essa solução para tais coisas que eu estou pensando! Quem sabe vou por outro caminho usando isso. A referência te leva muitas vezes a buscar uma outra saída para o que você está pretendendo, encontrar outra coisa a partir do que está na tua frente. E outros objetos que estão ali, garrafas, coisas guardadas nas prateleiras, todas elas têm repercussão, evidentemente. Os objetos não são neutros na vida da gente, eles dizem coisas mesmo quando você não os usa. Eu por exemplo, sou muito cuidadoso, (para usar um termo generosol com os objetos que tenho, com as coisas que eu possuo e gosto. Não gosto que mexam e não gosto de mudá-los de lugar. Encontrar os objetos que eu deixei no lugar, e que estejam lá. Como se fosse um ser que está aí. Eu não tinha parado para verbalizar isso com vocês, mas é evidente, a influência se dá entre vocês, quando trocam experiências conversando, vendo coisas. Mas todo o pessoal do ateliê faz aquisições pessoais, cresce vendo coisas que estão aí, as telas são objetos, os quadros são objetos, as gravuras também são objetos presentes. Só que no nosso caso, não são só objetos, é por isso que também possuem outro tipo de repercussão. 